\title{
Intrahepatic Bile Duct Cancer Pathologic Primary Tumor TNM Finding v8
}

National Cancer Institute

\section{Source}

National Cancer Institute. Intrahepatic Bile Duct Cancer Pathologic Primary Tumor TNM

Finding v8. NCI Thesaurus. Code C134586.

A pathologic finding about one or more characteristics of intrahepatic bile duct cancer, following the rules of the TNM AJCC v8 classification system as they pertain to staging of the primary tumor. 